\title{
Exploratory Analyses for Water Quality of the Gulf of Mexico Basin, Texas, 2005-2014
}

\author{
Faye Anderson, Najla N. J. Al-Thani \\ Center for Advances in Water and Air Quality, Lamar University, Beaumont, TX, USA \\ Email: andersonfaye7@gmail.com
}

Received 6 December 2015; accepted 9 January 2016; published 12 January 2016

Copyright (C) 2016 by authors and Scientific Research Publishing Inc.

This work is licensed under the Creative Commons Attribution International License (CC BY).

http://creativecommons.org/licenses/by/4.0/

\begin{abstract}
With the increased demand for more water sources, the issues of water quality have become more important. This study presents exploratory data analyses on water quality issues related to the Gulf of Mexico Basin in Texas for the last decade: 2005-2014. Dissolved oxygen, water temperature, specific conductance, $\mathrm{PH}$, transparency, sampling depth and Enterococci observations for the ten years from 2005 to 2014 were analyzed. Statistical testing showed that the observations followed similar distributions between the years. Thus they were combined for each of the variables. Throughout the ten years transparency, water temperature, specific conductance, and Enterococci showed higher variances. Pair-wise correlations were negligible but they had positive spatial autocorrelation. Sampling was constantly conducted in the four months of February, May, August, and November. Water temperature, dissolved oxygen and Enterococci concentrations varied significantly during these four months. Univariate spatial regressions showed that Enterococci is predicted to increase whereas dissolved oxygen, $\mathrm{PH}$, water temperature, specific conductances were predicted to decrease.
\end{abstract}

\section{Keywords}

Surface Water, Water Quality, Gulf of Mexico Basin, Texas, Multivariate, Spatial, Stormwater Flooding, Community Adaptive Capacity, Resilience

\section{Introduction}

In the summer of 2015, many warnings were issued in Texas cautioning against water recreational activities because of detection of high levels of Enterococci. This was substantiated by the increased risks that face the population especially those engaging in recreational activities in surface waters due to presence of disease-causing microorganisms, which led to the 1999 U.S. Environmental Protection Agency (EPA) Action Plan for Beaches 
and Recreational Waters [1]. Increased levels of Enterococci in water are positively associated with increased cases of gastroenteritis [2]. One of the most important sources of bacterial contamination in the state is storm water flooding which flows into beaches [3]-[5]. This is not an isolated issue as this contamination causes further contamination to groundwater, which is getting increasingly scarce. Increased levels of fecal bacteria is not the only problem facing quality water in Texas [6] [7]. Moreover, these increased detections of Enterococci contamination point to issues with community resilience and its adaptive capacity against flooding [8] [9].

This study aimed at assessing surface water quality in the Gulf of Mexico Basin in Texas, in the last decade from 2005 to 2014, by conducting temporal and spatial exploratory analyses for six of the most important parameters: Dissolved oxygen, PH, specific conductance, water temperature, transparency, and levels of Enterococci. Dissolved oxygen is one of the most important measurements of fresh water because of its significance to aquatic organisms especially fish. It is measured in milligrams per liter (mg/l). Oxygen is produced during photosynthesis. Excessive plant growth consumes more oxygen than its production leading to decreased levels of dissolved oxygen in the water. Oxygen solubility in water is negatively associated with each water temperature and salinity. Increased levels of bacteria reduce levels of dissolved oxygen in water. Another source of oxygen in water is diffusion from the atmosphere. PH measures acidity of water with a scale from 0 to 14, 7 being neutral and a PH of greater than 7 being alkaline. Just as dissolved oxygen is important for aquatic life, a PH between 5 and 9 is necessary for healthy aquatic organisms' wellbeing. Algal bloom increases PH levels and can be lethal to aquatic organisms. Specific conductance is a measure of water's capability to conduct an electric current and is the ratio of current to voltage between any two points in micro Siemens per centimeter $(\mu \mathrm{S} / \mathrm{cm})$ within water corrected to $25^{\circ} \mathrm{C}$. Water temperature is an essential indicator for healthy aquatic life because it can point to levels of dissolved oxygen. Transparency is a measure of water clarity and is important for sunlight to reach aquatic plants. Enterococci are a sub-group of fecal streptococci usually found in intestines of mammals and humans. The Texas Commission on Environmental Quality (TCEQ) standard for Enterococci in fresh water is 168 mostprobable number (MPN)/100 ml and it is measured as an indicator for fecal contamination in water [2] [10][12].

\section{Methods}

Shapefile for Texas surface water quality monitoring stations was downloaded from TCEQ's website (http://www.tceq.state.tx.us/gis/download-tceq-gis-data). Field water quality observations were downloaded from TCEQ Clean Rivers Program (CRP) website

(http://www80.tceq.texas.gov/SwqmisWeb/public/crpweb.faces). Variables collected were dissolved oxygen $(\mathrm{mg} / \mathrm{l})$, water temperature $\left({ }^{\circ} \mathrm{C}\right)$, specific conductance $\left(\mu \mathrm{S} / \mathrm{cm}\right.$ at $\left.25^{\circ} \mathrm{C}\right), \mathrm{PH}$, transparency (Secchi disc) (m), depth (m), and Enterococci in the (MPN/100 ml) methodology; for the ten years from 2005 through 2014. In addition, locations of stations were recorded in longitude and latitude (Figure 1).

\section{Results and Discussion}

Data (3880 observations) came from seven monitoring stations: Gulf of Mexico at county line, Gulf of Mexico at Mc Fadden Beach Louisiana, Gulf of Mexico at port Aransas, Gulf of Mexico at Port Isabel, Gulf of Mexico at Sea Rim Park, Gulf of Mexico off Louisiana coast, and Gulf of Mexico Sabine pass (Figure 1). Annual observations numbers ranged from 317 (in 2008) to 482 (in 2006). Nevertheless, sampling was not done in every month (Figure 2). In the ten years, sampling has always been conducted in the four months of February, May, August, and November, or every three months starting from February. Exploratory data analyses (Table 1) showed that Dissolved oxygen averaged $7.07 \mathrm{mg} / \mathrm{l}$, PH averaged 8.02, specific conductance averaged 4,102,676 $\mu \mathrm{S} / \mathrm{cm}$ at $25^{\circ} \mathrm{C}$, water temperature averaged $22.60^{\circ} \mathrm{C}$, transparency averaged $0.83 \mathrm{~m}$, and Enterococci averaged 1023.11 MPN/100 ml. Depth of sampling averaged $5.5 \mathrm{~m}$ except for transparency $(0.30 \mathrm{~m})$. Variation for dissolved oxygen, $\mathrm{PH}$, water temperature, transparency, and sampling depth was not significant, but it was distinctively variant for specific conductance.

In order to test for temporal variation for the six throughout the ten years, Fisher's F-test was used to test the null hypothesis of similar variances and t-test was used to test the null hypothesis of similar means. $P$-values for both tests were greater than the significance level of 0.05 . Hence the null hypotheses of similar means and variances could not be rejected for each of the six variables. This means that each variable does not have between-year variation. Therefore, all records for the different years were combined for each variable. Temporal 


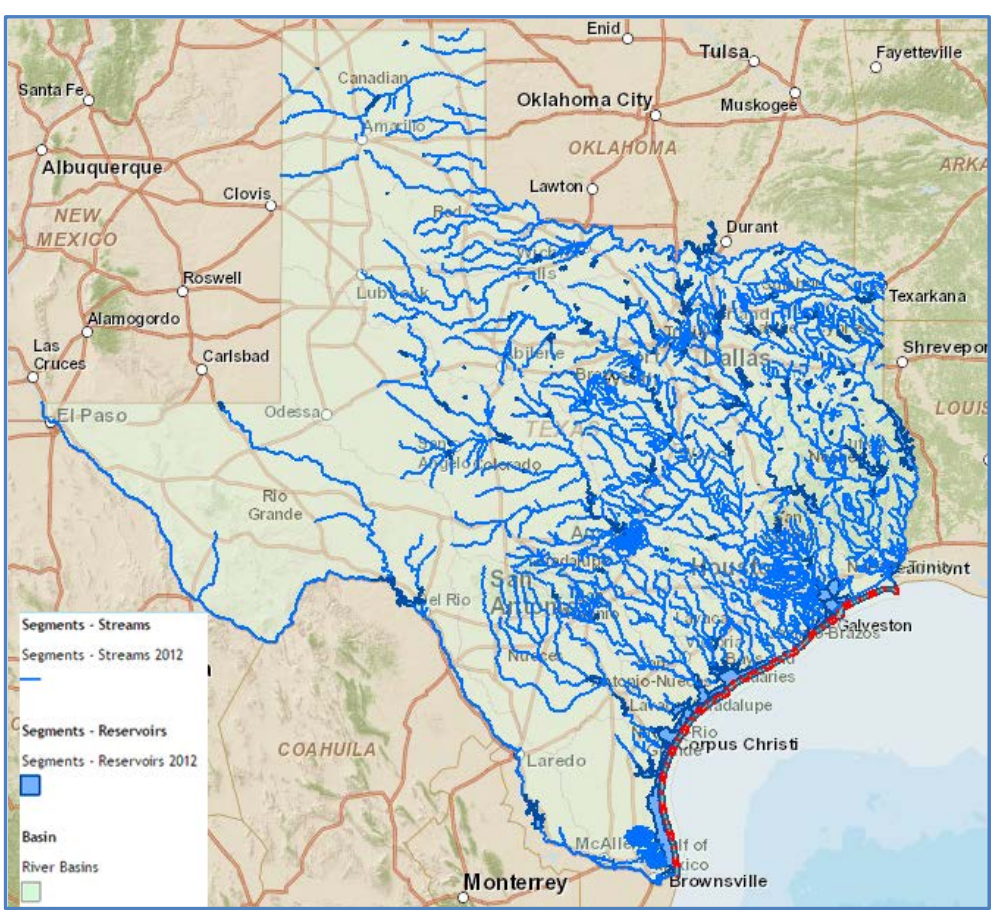

Figure 1. Gulf of Mexico Basin, Texas.

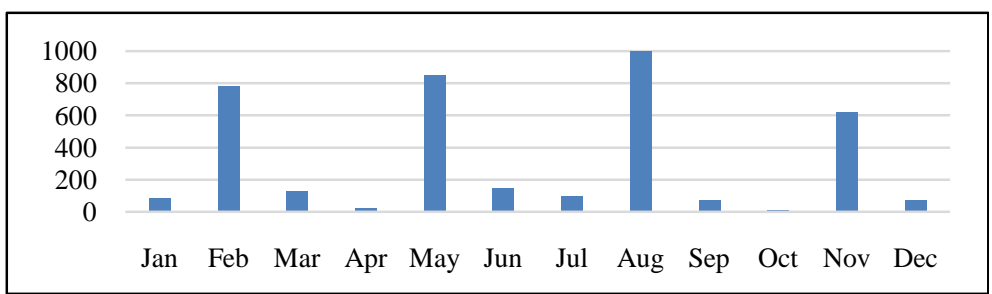

Figure 2. Monthly number of observations, 2005-2014.

Table 1. Descriptive statistics, 2005-2014.

\begin{tabular}{|c|c|c|c|c|c|c|c|}
\hline Parameter & Count & Min & Mean & Max & Std. Dev. & Skewness & Kurtosis \\
\hline Dissolved Oxygen (mg/l) & 899 & 0.60 & 7.07 & 15.99 & 1.72 & 0.20 & 1.23 \\
\hline $\mathrm{PH}$ & 936 & 6.90 & 8.02 & 9.30 & 0.24 & -0.16 & 4.17 \\
\hline Specific Conductance $\left(\mu \mathrm{S} / \mathrm{cm}\right.$ at $\left.25^{\circ} \mathrm{C}\right)$ & 918 & 2200.00 & $41,026.76$ & $59,700.00$ & $11,353.51$ & -0.90 & 1.01 \\
\hline Water Temperature $\left({ }^{\circ} \mathrm{C}\right)$ & 936 & 2.10 & 22.60 & 34.60 & 6.29 & -0.40 & -0.74 \\
\hline Transparency (m) & 191 & 0.01 & 0.83 & 5.00 & 0.90 & 1.68 & 2.79 \\
\hline Depth (m) & 3880 & 0.30 & 5.28 & 19.00 & 4.64 & 0.56 & -0.90 \\
\hline Enterococci (MPN/100 ml) & 162 & 1.00 & 1023.11 & 4800 & 1773.39 & 1.52 & 0.52 \\
\hline
\end{tabular}

trends for dissolved oxygen, $\mathrm{PH}$, water temperature, transparency and specific conductance in the past decade are given in Figure 3. Over the ten years $\mathrm{PH}$ and transparency seemed to be stable, whereas dissolved oxygen, water temperature, specific conductance, and Enterococci showed higher variations. Pair-wise correlations were negligible between the six variables as shown in Table 2. This does not necessarily mean lack of spatial association. This also signifies the presence of redundant information in georeferenced data [13].

Figure 4 and Figure 5 give the seasonal trends for dissolved oxygen, transparency, PH, water temperature, 
Table 2. Pearson pair-wise correlations.

\begin{tabular}{|c|c|c|c|c|c|c|}
\hline & Temperature & Transparency & $\begin{array}{c}\text { Specific } \\
\text { Conductance }\end{array}$ & $\begin{array}{l}\text { Dissolved } \\
\text { Oxygen }\end{array}$ & $\mathrm{PH}$ & Enterococci \\
\hline Temperature & 1.00 & 0.03 & 0.08 & 0.19 & 0.07 & 0.13 \\
\hline Transparency & & 1.00 & 0.06 & 0.08 & 0.03 & 0.08 \\
\hline Specific Conductance & & & 1.00 & 0.18 & -0.01 & -0.03 \\
\hline Dissolved Oxygen & & & & 1.00 & -0.02 & 0.14 \\
\hline $\mathrm{PH}$ & & & & & 1.00 & 0.03 \\
\hline Enterococci & & & & & & 1.00 \\
\hline
\end{tabular}

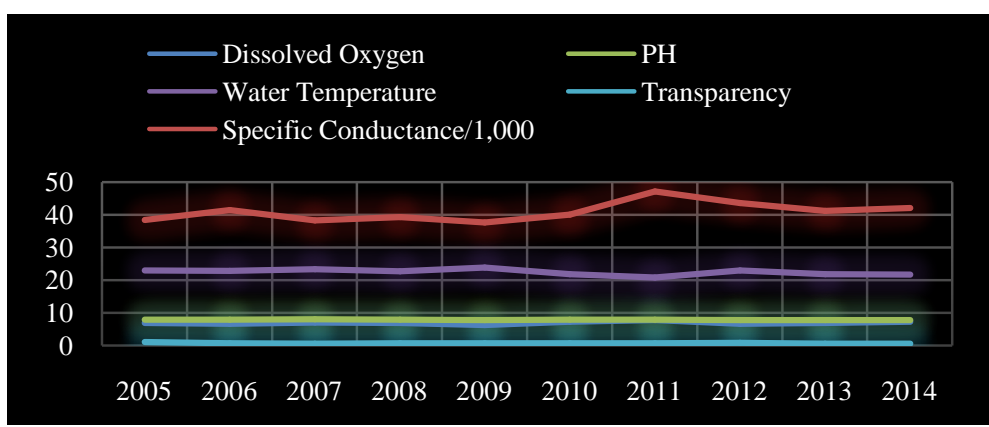

Figure 3. Temporal trends for dissolved oxygen, PH, water temperature, transparency and specific conductance.

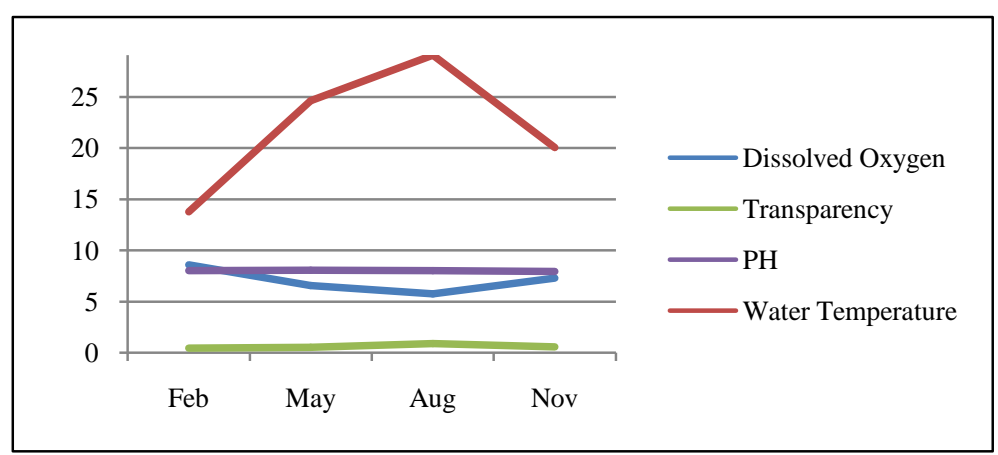

Figure 4. Seasonal trends for dissolved oxygen, $\mathrm{PH}$, water temperature, and transparency.

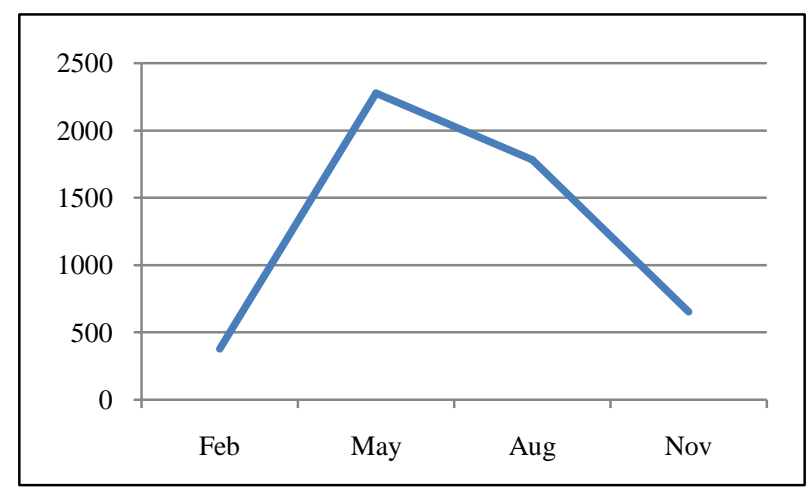

Figure 5. Seasonal trends for Enterococci (MPL/100 ml). 
Table 3. Results of univariate spatial regressions on longitude and latitude.

\begin{tabular}{cc}
\hline Dependent Variable & $\mathrm{R}^{2}(\%)$ \\
\hline Enterococci & 2 \\
Dissolved Oxygen & 30 \\
PH & 20 \\
Water Temperature & 98 \\
Specific Conductance & 59 \\
\hline
\end{tabular}

and Enterococci. The only observable trend is the decrease of oxygen solubility from May through August accompanied by increase in water temperature. This can be explained by decreased oxygen solubility as water temperature rises [6]. Because the number of transparency observations was way smaller than that for the other variables, it was excluded from subsequent analyses. Skewness of dissolved oxygen, $\mathrm{PH}$, specific conductance, and water temperature were not too far from zero. Nevertheless, Shapiro test for these four variables produced a $p$-value less than the significance level of 0.05 . Thus the null hypotheses that they came from normal distribution was rejected and a log transformation was applied. Moran I test for spatial autocorrelation showed that except for transparency, all other variables had positive spatial autocorrelation. That is, their observations cluster together spatially. Univariate regressions on longitude and latitude showed that Enterococci is predicted to increase $\left(R^{2}=0.02\right)$ whereas dissolved oxygen $\left(R^{2}=0.30\right)$, $\mathrm{PH}\left(R^{2}=0.20\right)$, water temperature $\left(R^{2}=0.98\right)$, and specific conductance $\left(R^{2}=0.59\right)$ are predicted to decrease (Table 3 ).

Although this study started with the purpose of quantifying water quality temporal and spatial trends in the Gulf of Mexico Basin in Texas, the results point to major issues that policy makers and researchers need to address. Future studies are recommended to investigate other important parameters like salinity, the investigation of multivariate geostatistical modeling, and the inclusion of more monitoring sites. These can help draw a bigger picture of the factors leading to water contamination and can provide interpretations for issues related to groundwater contamination. More importantly, this study points to lack of sufficient collaboration between risk mitigation planners and public health practitioners to connect the cases of bacterial infections to risks facing the communities especially stormwater flooding. Also, continuous assessment of potential parameters of water quality is recommended. Finally, multi-pollutant framework should be explored.

\section{Conclusion}

Different analyses were used to assess the temporal and spatial variations of water in the Gulf of Mexico Basin, Texas. Statistical analyses showed marginality of pair-wise associations, presence of positive spatial autocorrelation, minimal temporal variance for the parameters except for specific conductance and Enterococci, increased water temperature during the summer and fall, decreased levels of dissolved oxygen during the summer and fall seasons, expected increase in Enterococci and forecasted decrease in dissolved oxygen, $\mathrm{PH}$, water temperature, and specific conductance. Despite the need to investigate other important parameters, the results of this study pointed to the need to have more integrated efforts to control storm water flooding in order to control the expected increase in Enterococci in surface water and consequently to increase the community's health and adaptive capacity.

\section{References}

[1] U.S. Environmental Protection Agency (1999) Action Plan for Beaches and Recreational Waters. EPA/600/R-98/079. Office of Water, U.S. Environmental Protection Agency, Washington DC.

[2] TCEQ (2007) Texas Water Quality Standards. http://www.bayoupreservation.org/html/DavenportOverviewSymposium.pdf

[3] Oshiro, R. and Fujioka, R. (1995) Soil, and Pigeon Droppings: Sources of Indicator Bacteria in the Waters of Hanauma Bay, Oahu, Hawaii. Water Science \& Technology, 31, 251-254. http://dx.doi.org/10.1016/0273-1223(95)00275-R

[4] Olapade, O.A., Depas, M.M., Jensen, E.T. and McLellan, S.L. (2006) Microbial Communities and Fecal Indicator 
Bacteria Associated with Cladophora Mats on Beach Sites along Lake Michigan Shores. Applied and Environmental Microbiology, 72, 1932-1938. http://dx.doi.org/10.1128/aem.72.3.1932-1938.2006

[5] Yoder, J.S., Blackburn, B.G., Craun, G.F., Hill, V., Levy, D.A., Chen, N., Lee, S.H., Calderon, R.L. and Beach, M.J. (2004) Surveillance for Waterborne-Disease Outbreaks Associated with Recreational Water-United States, 2001-2002. MMWR Surveillance Summaries, 53, 1-22.

[6] USGS (2015) Groundwater Quality. http://water.usgs.gov/edu/earthgwquality.html

[7] Anderson, F. (2014) Multivariate Geostatistical Model for Groundwater Constituents in Texas. International Journal of Geosciences, 5, 1609-1617. http://dx.doi.org/10.4236/ijg.2014.513132

[8] Anderson, F. and Al-Thani, N.J. (2015) Sustainability Atlas of Texas Ecoregions. Journal of Human Resource and Sustainability Studies, 3, 203-210. http://dx.doi.org/10.4236/jhrss.2015.34026

[9] Anderson, F. and Al-Thani, N.J. (n.d.) Reviewing Methods of Assessing Community Adaptive Capacity: A Case Study from Jefferson County, Texas. in press.

[10] Ahmed, B. and Sinha, R.K. (2014) Rivers for Life: Proceedings of the International Symposium on River Biodiversity: Ganges-Brahmaputra-Meghna River System. IUCN, Nature.

[11] Fewtrell, L. and Bartram, J. (2001) Water Quality: Guidelines, Standards, and Health: Assessment of Risk and Risk Management for Water-related Infectious Disease. IWA Publishing.

[12] USGS (2015) Water Properties: Dissolved Oxygen. http://water.usgs.gov/edu/dissolvedoxygen.html

[13] Cressie, N. (1991) Statistics for Spatial Data. Wiley, New York. 